\title{
19. STRONG FIELD MAGNETIC PROPERTIES OF BASALTS FROM DSDP LEG 26
}

\author{
J. M. Ade-Hall, Department of Geology, Dalhousie University, Halifax, Nova Scotia, Canada
}

\section{INTRODUCTION}

Measurement of the strong field magnetic properties of basalts often yields a quick indication of their alteration history, alteration having taken place either during initial cooling or during later hydrothermal alteration following burial by younger rocks (Ade-Hall et al., 1971). The main indicator of alteration history is the Curie temperature, but the shape of magnetic momenttemperature profiles and the magnetic changes that take place during thermal cycling may also yield useful information.

\section{METHOD}

Approximately $10-\mathrm{mg}$ chips of basalt were heated in a small furnace situated between the Faraday pole pieces of a $7.5-\mathrm{kg}$ electromagnet. Heating rates, in air, were in excess of $200^{\circ} \mathrm{C} / \mathrm{min}$. These high rates were used in order to reach initial Curie temperatures before alteration could take place in the many magnetically highly metastable samples. Changes in magnetic moment were recorded using a Cahn R 100 electrobalance. The output from the electrobalance was fed to the $\mathrm{Y}$ scale of a BBN $815 \mathrm{M} \mathrm{X}-\mathrm{Y}$ recorder, with temperature recorded on the $\mathrm{X}$ scale.

\section{RESULTS}

The results are summarized in Table 1 and illustrated in Figure 1. The salient features of the results are the wide range of Curie temperatures and types of thermomagnetic curves, both between and within sites. A number of simple reversible curves with low $\left(\leq 240^{\circ} \mathrm{C}\right)$ Curie temperatures (e.g., Hole 250A, Curves 1 and 2 and Site 256 , Curves 2 to 5 ) indicate that a single phase, little altered titanomagnetite is the magnetic phase of the samples. Curves showing intermediate Curie points $\left(240^{\circ}<\mathrm{Tc}<500^{\circ} \mathrm{C}\right)$ probably represent titanomagnetite that have experienced various degrees of hydrothermal alteration leading to cation deficient forms (Readman and O'Reilly, 1970). An interesting class of curves for samples in this state show an initial rise in moment on heating (Site 251, Curves 1 and 4; Site 256, Curve 1). This is the most thermally unstable state known for basalts. Phase splitting always takes place very rapidly during heating, and it is often difficult to determine the initial Curie temperature. Phase splitting produces nearly pure magnetites and ilmenites, with a dramatic rise in Curie point and saturation moment.

Curie temperatures of greater than $500^{\circ} \mathrm{C}$ represent low titanium titanomagnetite produced by the subsolidus exsolution of ilmenite following high-temperature oxidation during initial cooling (e.g., Site 254, Curve 3 and the high Curie points of Site 254, Curves 1 and 2). With this interpretation of thermal curves in mind, we see that partial alteration of the magnetites, and thus probably of samples in general, is widespread. All the samples from Hole 251A and Site 253 and some from Sites 256 and 257 have probably experienced lowtemperature hydrothermal alteration, while the samples from Site 254 have experienced different degrees of deuteric oxidation. The particular points are of interest. The mean Curie temperatures for sites do not relate simply to geographic location, and in particular to the nearest spreading ridge, as is the case in the Atlantic at $45^{\circ} \mathrm{N}$ (Schaeffer and Schwartz, 1970). Again, there is no clear systematic variation of Curie temperature with depth at Site 257, from which 11 samples were available. However, there is a clear inverse relationship between Curie temperature and the presence of secondary hematite at this (Figure 2) and other sites.

\section{REFERENCES}

Ade-Hall, J. M., Palmer H. C., and Hubbard, T. P., 1971. The magnetic and opaque petrological response of basalts to regional hydrothermal alteration: Roy. Astron. Soc. Geophys. J., v. 24, p. 137.

Readman, P. W. and O'Reilly, W., 1970. The systhesis and inversion of non-stoichiomatric titanomagnetites: Phys. Earth Planet. Int., v. 4, p. 121.

Schaeffer, R. M. and Schwartz, E. J., 1970. The Mid-Atlantic Ridge at $45^{\circ} \mathrm{N}$. IX. Thermomagnetics of dredge samples of igneous rocks: Canadian J. Earth Sci., v. 7, p. 268. 
TABLE 1

Strong Field Magnetic Properties of Basement Rocks (See also Figures 1 and 2)

\begin{tabular}{|c|c|c|c|}
\hline $\begin{array}{c}\text { Sample } \\
\text { (Interval in } \mathrm{cm} \text { ) }\end{array}$ & $\begin{array}{l}\text { Saturation } \\
\text { Magnetization } \\
\text { at } 21^{\circ} \mathrm{C} \\
\text { (Arbitrary Units) }\end{array}$ & $\begin{array}{l}\text { Curie Temperature } \\
\text { During Heating } \\
\text { Cycle }\left({ }^{\circ} \mathrm{C}\right)\end{array}$ & $\begin{array}{l}\text { Significant Features } \\
\text { of } \mathrm{J}_{\mathrm{S}-\mathrm{T}} \text { Curves }\end{array}$ \\
\hline $\begin{array}{ll}250 \mathrm{~A}-26-2, & 140 \\
250 \mathrm{~A}-26-6, & 58\end{array}$ & $\begin{array}{l}0.731 \\
0.537\end{array}$ & $\begin{array}{l}238 \\
224\end{array}$ & \\
\hline $\begin{array}{ll}251 \mathrm{~A}-31-2, & 84 \\
251 \mathrm{~A}-31-3, & 50 \\
251 \mathrm{~A}-31-4, & 48\end{array}$ & $\begin{array}{l}\text { not available } \\
2.08 \\
1.12\end{array}$ & $\begin{array}{l}298 \\
528 \\
394,482\end{array}$ & $\begin{array}{l}\text { Nearly reversible. } \\
\text { Double Curie point could arise from alter- } \\
\text { ation during heating cycle. } 2 \% \text { initial rise in } \\
\text { moment on heating. Great increase in mo- } \\
\text { ment from } 522^{\circ} \mathrm{C} \text { Curie point during cooling } \\
\text { cycle. }\end{array}$ \\
\hline $251 \mathrm{~A}-31-5,105$ & 0.972 & 460 & $\begin{array}{l}3 \% \text { initial rise in moment on heating. Steep } \\
\text { rise in moment from } 548^{\circ} \mathrm{C} \text { Curie point } \\
\text { during cooling cycle. }\end{array}$ \\
\hline $253-58, \mathrm{CC}$ & 1.45 & 536 & Reversible curve. \\
\hline $254-31-1,111$ & 0.512 & 274,514 & $\begin{array}{l}\text { Clear double Curie point. Lower Curie point } \\
\text { absent in cooling cycle. }\end{array}$ \\
\hline $\begin{array}{l}254-35-1,107 \\
254-36-3,105\end{array}$ & $\begin{array}{l}0.334 \\
0.857\end{array}$ & $\begin{array}{l}332,534 \\
564,(650)\end{array}$ & $\begin{array}{l}\text { (as for Sample } 254-31-1,111 \mathrm{~cm} \text { ). } \\
\text { Reversible. Possible small hematite compo- } \\
\text { nent. }\end{array}$ \\
\hline $\begin{array}{l}256-9-2,12 \\
\quad \text { (green igneous rock) }\end{array}$ & 1.18 & 334 & $\begin{array}{l}2 \% \text { increase in moment on heating. Moment } \\
\text { reduced by } 60 \% \text { on cooling to room tempera- }\end{array}$ \\
\hline $\begin{array}{l}256-9-2,12 \\
\text { (green igneous rock plus } \\
\text { brown vein interval) }\end{array}$ & 0.370 & 302,610 & ture. $2 \%$ increase in moment on heating. \\
\hline $\begin{array}{l}256-10-2,68 \\
256-10-3,85 \\
256-11-1,15 \\
256-11-3,15\end{array}$ & $\begin{array}{l}2.43 \\
1.80 \\
1.37 \\
2.11\end{array}$ & $\begin{array}{l}224 \\
210 \\
198 \\
240\end{array}$ & \\
\hline $257-11-2,074$ & 0.420 & 354 & $\begin{array}{l}\text { Considerable loss of moment and mass after } \\
\text { thermal cycling. }\end{array}$ \\
\hline $257-11-3,130$ & 0.237 & 384 & \\
\hline $257-12-1,130$ & 0.313 & 382 & $\begin{array}{l}1.5 \% \text { increase in moment on heating. Great } \\
\text { increase in moment from } 536^{\circ} \mathrm{C} \text { Curie point } \\
\text { on cooling. }\end{array}$ \\
\hline $257-12-3,085$ & 0.890 & 366 & Reversible. \\
\hline $257-13-3,015$ & 0.440 & 348 & \\
\hline $257-14-2,095$ & 0.678 & 392 & \\
\hline $257-14-4,111$ & 1.27 & 278 & \\
\hline $257-15-1,133$ & 1.02 & 280 & \\
\hline $\begin{array}{l}257-16-2,145 \\
257-17-1,086\end{array}$ & $\begin{array}{l}0.677 \\
1.00\end{array}$ & $\begin{array}{c}302 \\
400,496\end{array}$ & $\begin{array}{l}\text { Clear double Curie point. Lower Curie point } \\
\text { absent on cooling cycle. }\end{array}$ \\
\hline $257-17-5,130$ & 0.938 & 328 & \\
\hline
\end{tabular}



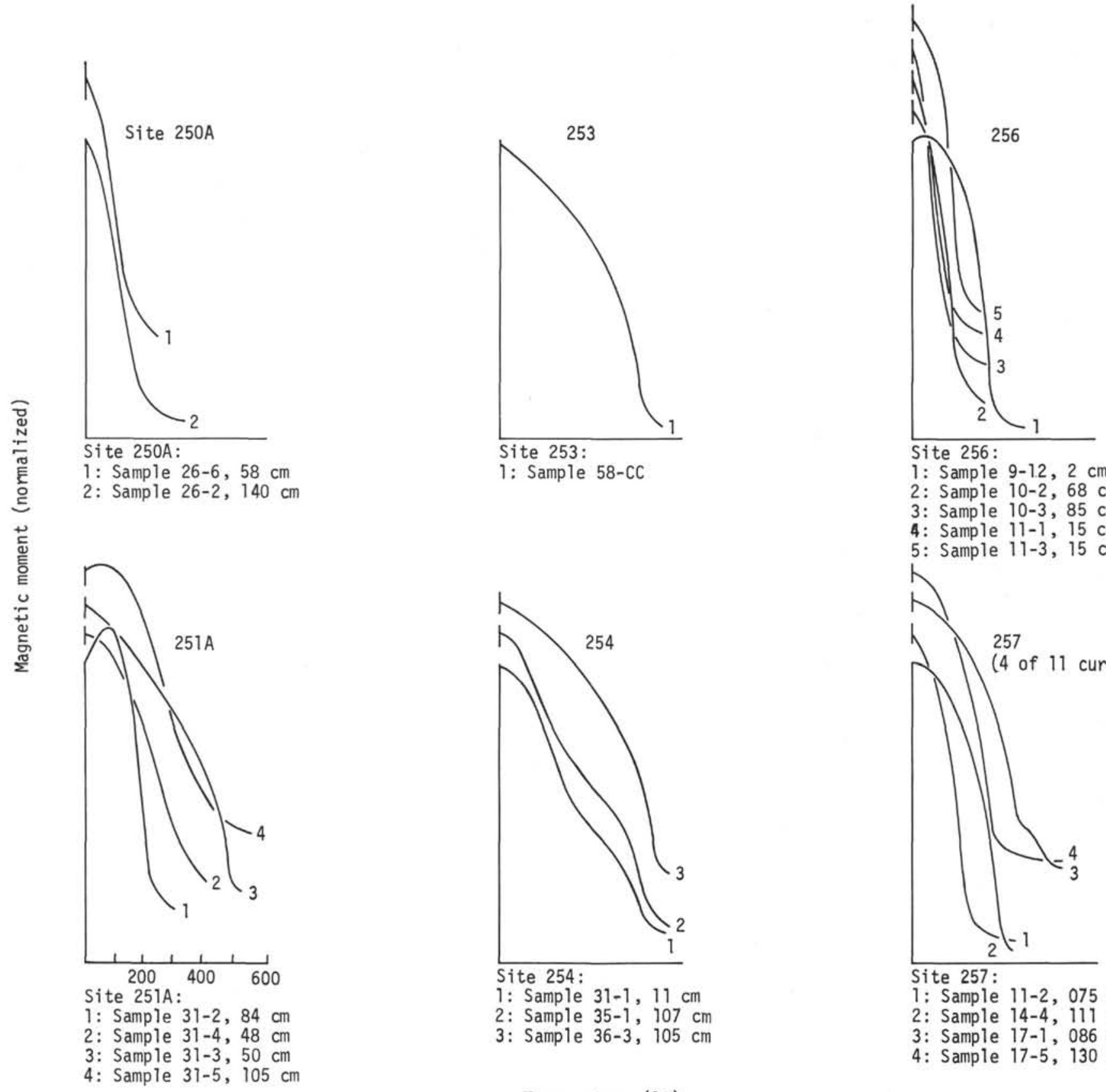

Site 256:

1: Sample 9-12, $2 \mathrm{~cm}$ 2: Sample 10-2, $68 \mathrm{~cm}$ 3: Sample 10-3, $85 \mathrm{~cm}$ 4: Sample $11-1,15 \mathrm{~cm}$ 5: Sample 11-3, $15 \mathrm{~cm}$

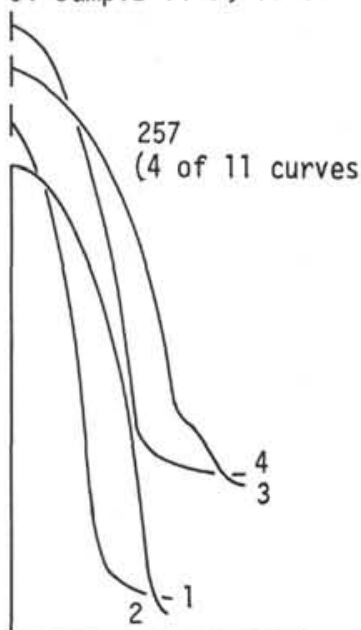

Site 254:

1: Sample 31-1, $11 \mathrm{~cm}$ 2: Sample 35-1, $107 \mathrm{~cm}$

Site 257 :

1: Sample 11-2, 075 on 2: Sample 14-4, $111 \mathrm{~cm}$ 3: Sample 17-1, $086 \mathrm{~cm}$ 3: Sample 36-3, $105 \mathrm{~cm}$

4: Sample 17-5, $130 \mathrm{~cm}$

Temperature $\left({ }^{\circ} \mathrm{C}\right)$

Figure 1. Curves of thermal decay of saturation magnetics for Leg 26 basement samples. Note the general within-site and between-site variability in behavior. 
Curie temperature $\left({ }^{\circ} \mathrm{C}\right)$

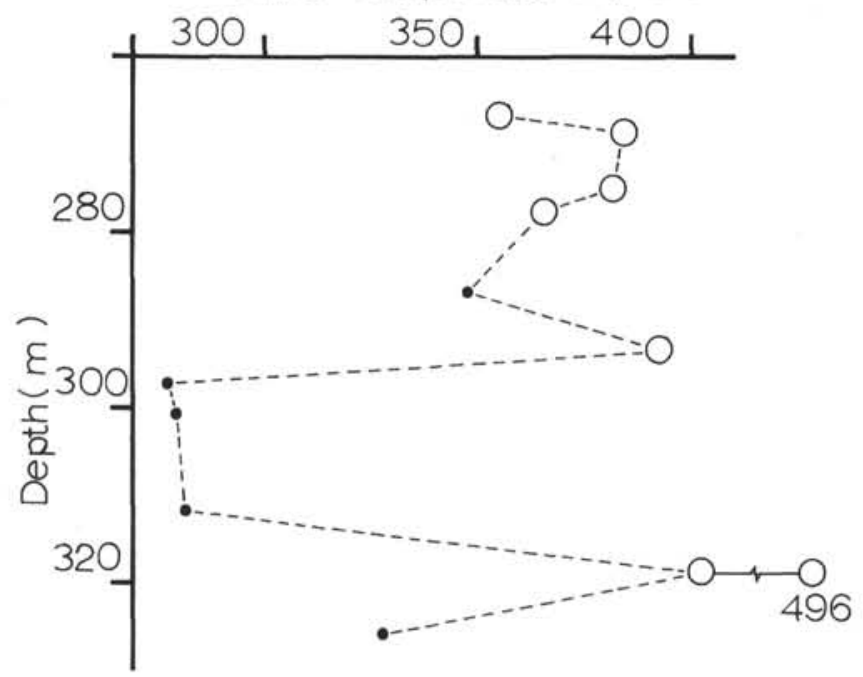

Figure 2. Curie temperature profile for Site 257. Large open circles are Curie temperatures for samples containing one or more forms of secondary hematite. Small closed circles are for secondary hematite-free samples. 